\title{
Tissue Factor Deficiency
}

National Cancer Institute

\section{Source}

National Cancer Institute. Tissue Factor Deficiency. NCI Thesaurus. Code C131635.

A coagulation disorder characterized by the partial or complete absence of tissue factor (factor III) activity in the blood. 